\title{
Intermédialités
}

Histoire et théorie des arts, des lettres et des techniques

Intermediality

History and Theory of the Arts, Literature and Technologies

\section{Facing Severance}

\section{Mieke Bal}

Numéro 8, automne 2006

Envisager

Facing

URI : https://id.erudit.org/iderudit/1005547ar

DOI : https://doi.org/10.7202/1005547ar

Aller au sommaire du numéro

\section{Éditeur(s)}

Centre de recherche sur l'intermédialité

ISSN

1705-8546 (imprimé)

1920-3136 (numérique)

Découvrir la revue

Citer cet article

Bal, M. (2006). Facing Severance. Intermédialités / Intermediality, (8), 189-209. https://doi.org/10.7202/1005547ar

\section{Résumé de l'article}

Face au phénomène de migrations de masse vers l'Europe de l'Ouest, on a tendance à ignorer un groupe de personnes particulièrement affecte par le départ des jeunes : les mères de ceux qui quittent. Non seulement ont-elles vu leurs enfants quitter leur communauté, elles doivent également défendre leurs décisions - « c'est pour son bien » -, alors que leur vie a été marquées par une perte profonde. Ceci amena l'auteur de cet article à développer un projet vidéo dans lequel ces mères, jusqu'ici invisibles, ont l'occasion de parler de leurs enfants qui ont émigré. L'installation est tout entière portée par la question de "l'envisagement " (facing), tant à un niveau littéral, indirect, que figural. L'esthétique du gros plan, du cadrage unique, de l'absence de montage et, partant, du non-interventionnisme, ainsi que l'intimité du tournage et de la projection font de cette politique de « l'envisagement " une alternative viable à ce que Luc Boltanski appelle une " politique de la pitié ». Dans cet article, l'auteur développe le concept de ce projet, philosophiquement et sémiotiquement, à partir de Spinoza et de Deleuze, afin de montrer en quoi cette installation offre un exemple d'" esthétique migratoire » en tant qu'art politique.
Ce document est protégé par la loi sur le droit d'auteur. L'utilisation des services d'Érudit (y compris la reproduction) est assujettie à sa politique d'utilisation que vous pouvez consulter en ligne.

https://apropos.erudit.org/fr/usagers/politique-dutilisation/ 


\title{
Facing Severance
}

\author{
MIEKE BAL
}

\section{INTRODUCTION}

Imagine a gallery looking like a living room, where visiting is like a social call. The image is a portrait, bust only, of a woman speaking to someone else (apart from a short introductory sequence that sets up the situation). In some cases, we hear the voice of the interlocutor, in others we hear nothing but the women speaking. Every once in while, one of them falls silent, as if she were listening to the others.

The women are from various countries - for example, Gordana Jelenic from Serbia, Massaouda Tayeb Mehdi from Tunisia, Ümmühan Armagan from Turkey. They all live in their home country and all saw a child leave for Western Europe. They speak to someone else; the speech situation is personal. Their interlocutors are people close to them, intimates; but the relationship with them has been interrupted due to the migration of their child. If we are to understand and value the contribution of migrant cultures to the European scene, we must first of all realize the enormity of the consequences involved and the changes in the souls of individuals taking this drastic step. We must wonder, that is, why people think they must leave behind their affective ties, relatives, friends, and habits-in short, everything we take for granted to constitute everyday life. As I argue here, a first step to contemplating these questions is a triple act of facing.

Facing sums up the aesthetic and political principle of my ongoing video work Nothing is Missing that is an attempt to reflect on this severance and its consequences. Through this installation, I attempt to shift laterally both the notion of an individual autonomy of a vulgarized Cartesian cogito, and that of a subjecting passivity derived from the principle of Bishop Berkeley's "to be is to be perceived." The former slogan has done damage in ruling out the participation of the body

1. I thank Noa Roei for her expert help with the research for this paper, and Bregje van Eekelen for her keen textual criticism. I am increasingly feeling that what I write is first generated by the productive collaboration with them. 
and the emotions in rational thought. The latter, recognizable in the Lacanian as well as a certain Bakhtinian traditions, has sometimes over-extended passivity and coerciveness into a denial of political agency and hence, responsibility. ${ }^{2}$

I try to shift these views in favor of an intercultural, "relational" aesthetic. In order to elaborate such an alternative I have concentrated this installation on the bond between speech and face. Speech, not just in terms of "giving voice," but also as listening, and answering, all in multiple meanings; and the face, turning the classical "window of the soul" into an "inter-face." Between speech and facing lies a realm of intermediality. The medium of video, the medium of the moving image in, again, many different senses, is, I claim, eminently suitable to elaborate that bond in ways that return to aesthetics its old meaning of sensebased binding. Between "moving" as a multiple quality of the video image, and "binding" as a specific conception of aesthetics, I wish to articulate the concept of migratory aesthetics.

Facing, taken "at face value" is three things, or acts, at once. Literally, facing is, first, the act of looking someone else in the face. It is also, in second place coming to terms with something that is difficult to live down, by looking it in the face, instead of denying or repressing it. Thirdly, it is making contact, placing the emphasis on the second person, and acknowledging the need of that contact in order, simply, to be able to sustain life-instead of "to be is to be perceived" and "I think, therefore I am," facing proposes, "I face (you), hence, we are." For this reason, facing is my proposal for an emblematic instance of migratory aesthetics.

In this contribution-text and images-I will try to present migratory aesthetics as a useful approach to culture in the contemporary moving world-a world of mobility and affect. I will do so articulating what I have tried to do with the women through Nothing is Missing, through the stories that help us build the ever-denser and more complex network of subjectivities Spinoza called, after the Stoics, "world citizens."

2. The Cartesian tradition has been widely criticized. I only mention here the analysis by Lorraine Code, What Can She Know? Feminist Epistemology and the Construction of Knowledge, Ithaca, London, Cornell University Press, 1991. Lacan's view of the gaze, although brilliantly abducted for a political "ethics of vision" that avoids the trap of disempowerment in Kaja Silverman, The Threshold of the Visible World, 1996, New York, Routledge Press, 1996, has been taken to task for its pessimistic consequences by, among others, Norman Bryson, "The Gaze in the Expanded Field," in Hal Foster (ed.), in Vision and Visuality, San Francisco, The Dia Foundation, 1988, p. 87-114. Bakhtin's view of the constitution of identity by the gaze of others was criticized by Van Alphen in the chapter "Bodyscapes" of his study on Bacon (Ernst Van Alphen, Francis Bacon and the Loss of Self, London, Reaktion Books, 1992), and recently by Esther Peeren, Bakhtin and Beyond: Identities as Intersubjectivities in Popular Culture, Amsterdam, ASCA Press, 2005. 


\section{FROM ESSE EST PERCIPI TO COGITO TE ERGO SUMUS}

As Anthony Uhlmann has pointed out, Berkeley's formula as elaborated to exhaustion by Samuel Beckett is agony-inducing. 3 And, as it happens, linguistically this shows already in the mere fact that the formula defines being in non-personal forms. As a result, Beckett's Film (1965), he argues, explores the agonizing feelings that result from a consciousness of being through being perceived. Uhlmann points out that Beckett does not reject Berkeley's view but "exhausts" it, exploring the contours of Deleuze's three types of images. ${ }^{4}$

The figure played by the aging and decidedly not comical Buster Keaton flees from the notion of perceivedness, in the "action image." The sets of eyes that watch him and that he eliminates show us the limits of the "perception image," and the ending, the close-up of the "affection image" translates affect into horror only. In Nothing is Missing these three types of images are also at stake but not on a par, and instead culminate in the mitigated close-up of the face that shuttle between perception and affection image. Here, neither horror as a form of revolt, nor passive perceivedness as a handing over of human agency, but a rigorously affirmed second-personhood is the reply to this pessimistic view. The perceivedness that the predominance of close-up foregrounds, leads not to rejection or agony but to an empowering performativity.

Now, we have seen that the Cartesianism of the cogito is also easily reduced with the help of its linguistic structure. The notion that Descartes is the bad guy of enlightenment rationalism seemed to reduce him in the way he was seen as reducing human existence. Memories of my first readings of him as a first-year student of French-I remember an exercise of his visual description of a treedidn't square with that insensitive hyperrationalism imputed to him. So, when I come across references to a different Descartes-Hubert Damisch's baroque

3. Anthony Uhlmann, "Image and Intuition in Beckett's Film," Substance 104, Vol. 33, No. 2, 2004, p. 90-106.

4. Uhlmann's analysis is much richer than what I can sum up here. His main thrust is to recuperate Berkeley from this simplistic formula by expanding on its context: Berkeley's view of ideas as completely realized existence (Anthony Uhlmann, "Image and Intuition in Beckett's Film," p. 95), its consequences (in Bergson's theory of the image as brought about by intuition), and its current afterlife in Deleuze's theory of cinema, which is partly inspired by Beckett's Film (or his writings about that work). Beyond its ostensive topic (Beckett's film), Uhlmann's article is crucial for reflection on the image and visual art in general. 
dreamer, for example, 5 or Jean-Joseph Goux's tracing of Descartes' heritage to no other than Sophocles' Oedipus-I tend to prick up my ears.

Here, I am particularly keen on Goux's insight. To phrase his view in my own words and for my own purposes, according to him, the stake of the cogito is only secondarily the link between thinking and being, nor even the exclusive emphasis of reason and the excision of the body the formula seems to imply, but the double, tautological grammatical use of the first person. I think, [therefore] I am; the point is the possibility to describe human existence outside of the need to use the second person. ${ }^{6}$

Again, without imputing such a simple exclusionary vision to the great philosopher and astoundingly visual writer, the popularity of his formula has done more harm than good to western thought, especially in its exclusions, its excising not only of emotions from human existence, but also the dependency of human life on others. I call it an autistic version of subjectivity. Yet, this dependency on others is so obvious, and so absolute, that it may well be that inevitability that informed the desire to erase it. From the baby's mother to social caretakers to linguistic second persons, this dependency has been articulated clearly in psychoanalysis, sociology and linguistics, respectively. So much so, that being a second person seems more "natural" a definition of being human than anything else.

In the wake of a recent anti-cartesianism, with lots of babies and bathwater issues, the concept of "second-personhood" that feminist philosopher Lorraine Code has put forward7 is by now well-known enough to allow me to take a shortcut through it. It means that we cannot exist without others-in the eye of the other as much as in sustenance of others. That is where I would start any attempt to develop an idea of the aesthetic. Perhaps because of the keen interest I have kept in the second person not only of grammar but also of visual art, Goux's remark about the cogito's exclusion of the second person struck me forcefully and productively. Not to pursue the beating of the dead horse but on the contrary, to keep in mind the productivity of keeping returning with "critical intimacy" to

5. Hubert Damisch, Skyline: The Narcissistic City, trans. John Goodman, Stanford, California, Stanford University Press, 2001.

6. Jean-Joseph Goux, Edipe philosophe, Paris, Éditions Aubier, coll. "La psychanalyse prise au mot," 1990. I came across Goux's book in an extraordinary analysis of biblical and psychoanalytical discourse by French psychoanalyst Marie Balmary, Abel ou la traversée de l'Éden, Paris, Grasset, p. 39-41. Balmary's earlier book, L'homme aux statues: Freud et la faute cachée du père (Paris, Éditions Grasset, 1978) is a must-read for all those interested in the subtleties of language and the incidents of thought in both disciplines. I thank Jacqueline Duval for drawing my attention to Balmary's important writings.

7. Lorraine Code, What Can She Know?, and Rhetorical Spaces: Essays on Gendered locations, New York, Routledge Press, 1995. 


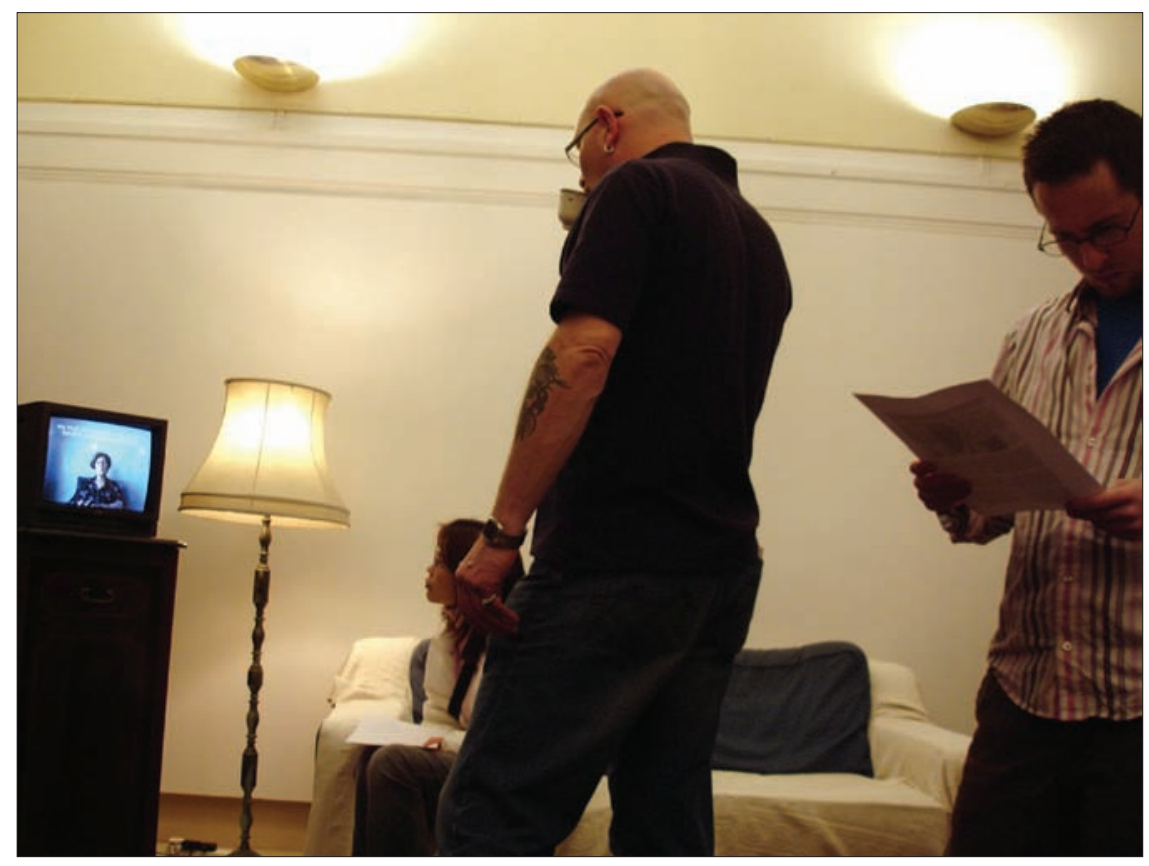

Fig. 1. Installation view of Nothing is Missing in the context of the exhibit Migratory Aesthetics, curated by Griselda Pollock, Leeds University, 2006. (C) Mieke Bal, 2006.

moments of the past, such as the dawn of rationalism in the 17th century. In this I am only joining a growing group of scholars, many influenced by Deleuze, his Spinoza and his Leibniz, and his fellow pre-posterous historian Bergson. ${ }^{8}$

8. The concept of "critical intimacy" comes from Gayatri Chakravorty Spivak (A Critique of Postcolonial Reason: Towards a History of the Vanishing Present, Cambridge, Harvard University Press, 1999) and has been developed in the last chapter of my Travelling Concepts in the Humanities: A Rough Guide (Toronto, University of Toronto Press, 2002). I have worked with, and further developed, second-personhood in chapter 5 of Double Exposures: The Subject of Cultural Analysis (New York, Routledge Press, 1996) for language in art history (Hubert Damisch, The Origin of Perspective, trans. John Goodman, Cambridge, MIT Press, 1994) and anthropology (Johannes Fabian, Time and the Work of Anthropology: Critical Essays, 1971-1991, Chur, Switzerland, Philadelphia, Harwood Academic Publishers, 1991), and in chapter 6 of Quoting Caravaggio: Contemporary Art, Preposterous History (Chicago, University of Chicago Press, 1999) for the painting of David Reed and the sculpture of Jeannette Christensen. 
Among these scholars, I call here on philosophers Moira Gatens and Genevieve Lloyd 9 who studied Descartes' contemporary, Baruch Spinoza. The line Spinoza-Bergson-Deleuze has led to extremely important and productive "revisionings" of the image, perception, and feeling that lie at the heart of my version of migratory aesthetics - of an aesthetics of geographical mobility beyond the nation-state and its linguistic uniformity. Gatens and Lloyd's short book is important here, because it does three things at once that are relevant for my project, to further the activity of "migratory aesthetics" and deploy the performative face in that context.

First, they invoke the relevance of Spinoza's work for a reasoned position in relation to aboriginal Australians' claim to the land that had been taken from them by European settlers. These claimants are not migrants since they stayed 194 put while their land was taken away from under them, but their claims are based on a culturally specific conception of subjecthood and ownership that makes an excellent case for the collective and historical responsibility the authors put forward with the help of Spinoza. And this responsibility is key to migratory aesthetics. It is a relation to the past that, today, we have to face.

That this "intercultural ethics" should be based on a 17th century writer who never met such claimants-although he can be considered a migratory subject-makes, second, a case for a historiography that I have termed "preposterous." This conception of history is focused on the relevance of present issues for a re-visioning of the past. In alignment with intercultural "relationality," we could call it intertemporal. Third, the authors make their case on the basis of the integration, an actual merging of Spinoza's ontological, ethical and political writings - three philosophical disciplines traditionally considered separately. This, of course, exemplifies interdisciplinarity. When we are considering different media, interdisciplinarity takes the special form of intermediality. Interdisciplinarity could be modeled on inter-facing in the sense I am developing here.

Against this background-my search for an aesthetic alternative to masochistic passivity and autism as a ground for migratory aesthetics-the face, with all the potential this concept-image possesses, seemed an excellent place to start. But to deploy the face for this purpose requires one more negative act, the elimination of an oppressive sentimentalist humanism that has appropriated the face in a threefold way: as the window of the soul, as the key to identity translated into individuality, and as the site of policing.

9. Moira Gatens, Genevieve Lloyd, Collective Imaginings: Spinoza, Past and Present, New York, Routledge Press, 1999. Henceforth, references to this text will be indicated by the initials "CI," followed by the page numbers, and placed between parentheses in the body of the text. 


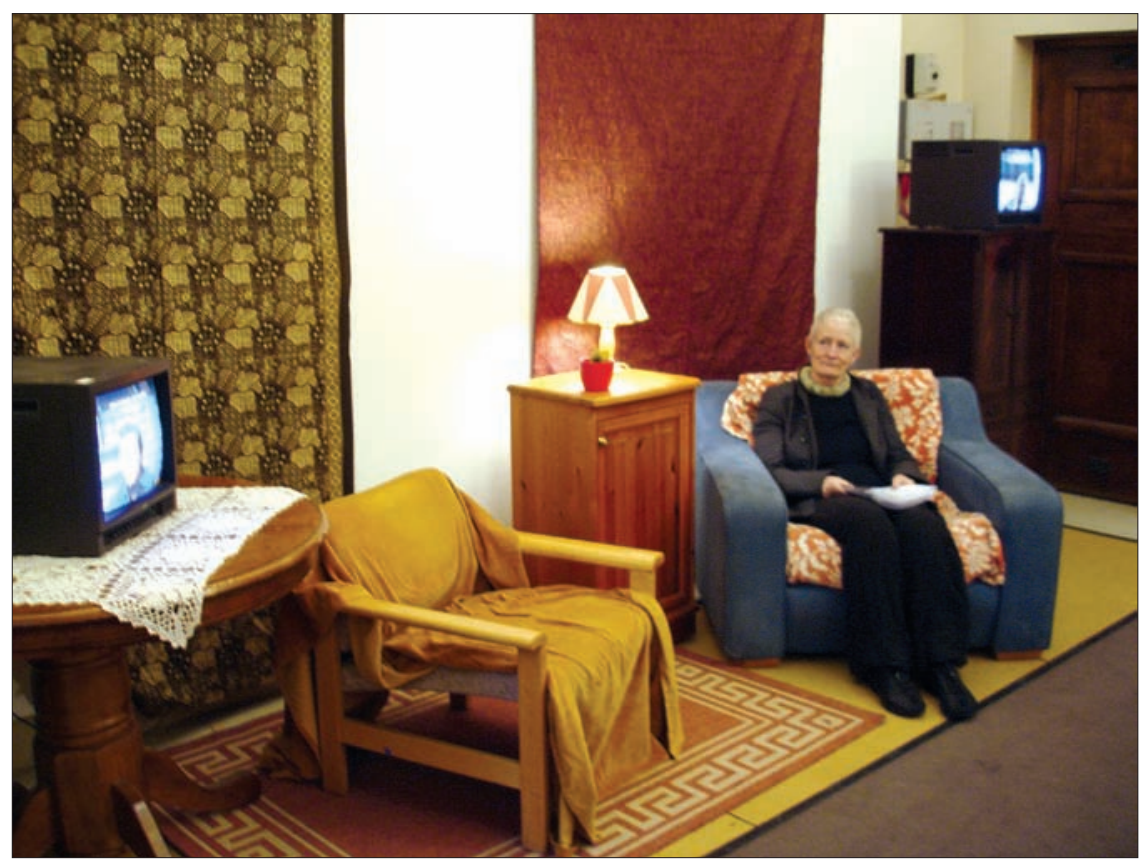

Fig. 2. Installation view of Nothing is Missing in the context of the exhibit Migratory Aesthetics, curated by Griselda Pollock, Leeds University, 2006. (c) Mieke Bal, 2006.

\section{IN THE BEGINNING WAS THE FACE}

Creation stories around the world tend to worry about the beginning of humanity in terms of the non-humanity that precedes it. Psychoanalysis primarily projects on the maternal face the beginning of the child's aesthetic relationality. Both discourses show their hand in these searches for beginnings. Here, I oppose an individualistic conception of beginnings. A few years after his path-breaking book Orientalism, the late Palestinian intellectual Edward Said wrote a book on the novels of the Western canon, titled Beginnings: Intention and Method. ${ }^{\circ}$ In this book he demonstrated that the opening of a literary work programs the entire text that follows, its content and its style, its poignancy and its aesthetic. It is the thesis of Nothing is Missing that this is true for cultural-political reality as well. Therefore, in this installation I wished to explore a different sense of the beginnings of migration. The primary question is: why people decide to leave behind their life as

10. Edward Said, Beginnings: Intention and Method, New York, Columbia University Press, 1985 . 
they know it. With this focus, I aim to invert the latent evolutionism in the search for beginnings, and, in the same sweep, the focus on children, on babies, inherent in individualistic theories of the subject.

The alleged centrality of the face as a definition of being human has not always been "natural." Artists practicing figurative representation depicted loose limbs and severed heads on the one hand, and scenes of fighting and murder in which bodies were difficult to disentangle on the other, as if to raise the question: what makes a body human? When is it still human, when does it cease to be so? The inquiry itself is evidence of the constructedness of the key function of the face. And today, with authorities displaying high anxiety over the invisibility of the Islamic veiled face, we cannot overestimate the importance not of the face per se but on the ideology of the face, for the construction of contemporary sociopolitical divides. ${ }^{11}$

Confusing, like so many others, origin with articulation, in his study of the portrait-the genre of the face-Richard Brilliant explains the genre with reference to babies:

The dynamic nature of portraits and the "occasionality" that anchors their imagery in life seem ultimately to depend on the primary experience of the infant in arms. The child, gazing up at its mother, imprints her vitally important image so firmly on its mind that soon enough she can be recognized almost instantaneously and without conscious thought $[\ldots]^{12}$

Like psychoanalysis, art history here grounds one of its primary genres in a fantasmatic projection of what babies see, do, and desire. Both disciplines can and must be challenged for their generalizations. ${ }^{13}$

The shift operates through the self-evident importance attributed to documentary realism, a second unquestioned value in Western humanist culture. The point of the portrait is the belief in the real existence of the person depicted, the

11. I made this argument in chapter 4 of my book Travelling Concepts in the Humanities, a propos of the popularity of myths of beheading such as the Judith story, following up on a suggestion made by Julia Kristeva, Visions capitales, Paris, Réunion des musées nationaux, 1998.

12. Richard Brilliant, Portraiture, Cambridge, Harvard University Press, 1991, p. 9. The term "occasionality" is borrowed from Hans-Georg Gadamer, Truth and Method, trans. Joel Weinsheimer, Donald G. Marshall, New York, Crossroad, 1989 (2nd rev. ed.). Brilliant uses it here to remain firmly on the side of documentary realism.

13. For a thorough critique of the discourse of portraiture, see the chapter on "The Portrait's Dispersal" in Van Alphen, Art in Mind: How Imagess Shape Contemporary Thought, Chicago, The University of Chicago Press, 2005. 


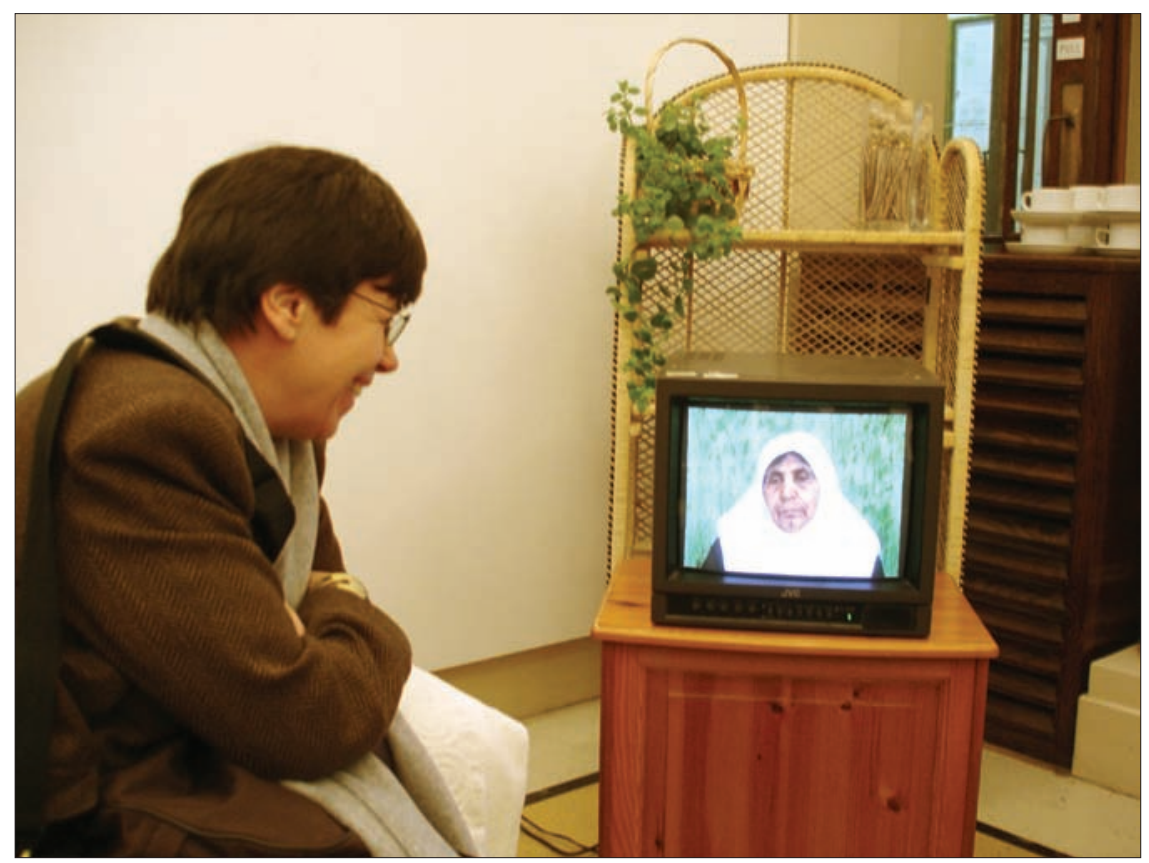

Fig. 3. Installation view of Nothing is Missing in the context of the exhibit Migratory Aesthetics, curated by Griselda Pollock, Leeds University, 2006. (C) Mieke Bal, 2006.

"vital relationship between the portrait and its object of representation." 14 The portraits that compose Nothing is Missing challenge these joint assumptions of individualism and realism and their claim to generalized validity. In order to do so with critical intimacy, however, the use of video is, again, significant.

The women in this work are, of course, "real," as real as you and me, and individual. And, at first sight, they have been documented as such. But at the same time, they speak "together" from within a cultural-political position that makes them absolutely distinct and absolutely connected at once. This is the meaning of the silences that suggests they are listening to one another, even if in reality they never met.

As for the documentary nature of their images, again, this is both obvious and obviously false, since the situation of speech is framed as both hyperpersonal and utterly staged. I filmed the migrants' mothers talking about their motivation to support or try to withhold their children who wished to leave and about their own grief to see them go. The mothers talk about this crucial moment in their past to a person close to them, often someone whose absence in her life was caused by the child's departure-a grandchild, a daughter-in-law, the child, him or herself.

14. Richard Brilliant, Portraiture, p. 8. 
The filming is, in one sense, excessively documentary. I staged the women, asked their interlocutors to take place behind the camera, set the shot, turned the camera on, and left the scene. This method is hyperbolically documentary. To underline this aspect I refrained from editing these shots. I will return to the resulting slow, unsmooth, and personal talk that results. ${ }^{15}$

Aesthetically, the women are filmed in consistent close-up, as portraits-the other side of the face of Brilliant's babies. The relentlessly permanent image of their face is meant to force viewers to look these women in the face, in the eyes, and listen to what they have to say, in a language that is foreign, using expressions that seem strange, but in a discourse to which we can all, affectively, relate. A third assumption of Brilliant's argument concerns the nature of identity. This again is based on the baby, enabled by seeing the mother's face, so that the ontogenetic perspective is constantly mapped on the phylogenetic one, in which development is the matrix and old equals primitive. ${ }^{16}$

This baby-basis is challenged most explicitly by the simple fact that the figures speaking here are the mothers, the other side of that face gazing up at them; the holders of the inter-face. The face as inter-face is neither the idealized Madonna nor the autistic mirror image but an occasion for an exchange that, affect-based as it may be, is fundamental in opening up the discourse of the face to the world.

A little later on the same page, Brilliant writes:

Here [in the mother-infant visual interaction] are the essential constituents of a person's identity: a recognized or recognizable appearance; a given name that refers to no one else; a social, interactive function that can be defined; in context, a pertinent characterization; and a consciousness of the distinction between one's own person and another's, and of the possible relationship between them. ${ }^{17}$

Crucially, this identity emerges not only out of appearance and naming but also out of distinction. Moreover, the recognition of appearance triggers interaction and expression. Typically for the cogito tradition, the two are practically the same:

15. The method of one-shot filming was disrupted only in the case of Massaouda when the daughter-in-law turned off the camera twice to allow her mother-in-law a break.

16. This is a well-known and criticized feature of Freud's thinking that has huge consequences for the bond between humanism and primitivism. See, for example, Marianna Torgovnick, Gone Primitive: Savage Intellectuals, Modern Lives, Chicago, University of Chicago Press, 1990.

17. Richard Brilliant, Portraiture, p. 8. The "given name that refers to no one else" is particularly striking here since the only example of this in the description on which this generalization is based is "Mama," an eminently social role. Again, mother and baby are collapsed. 


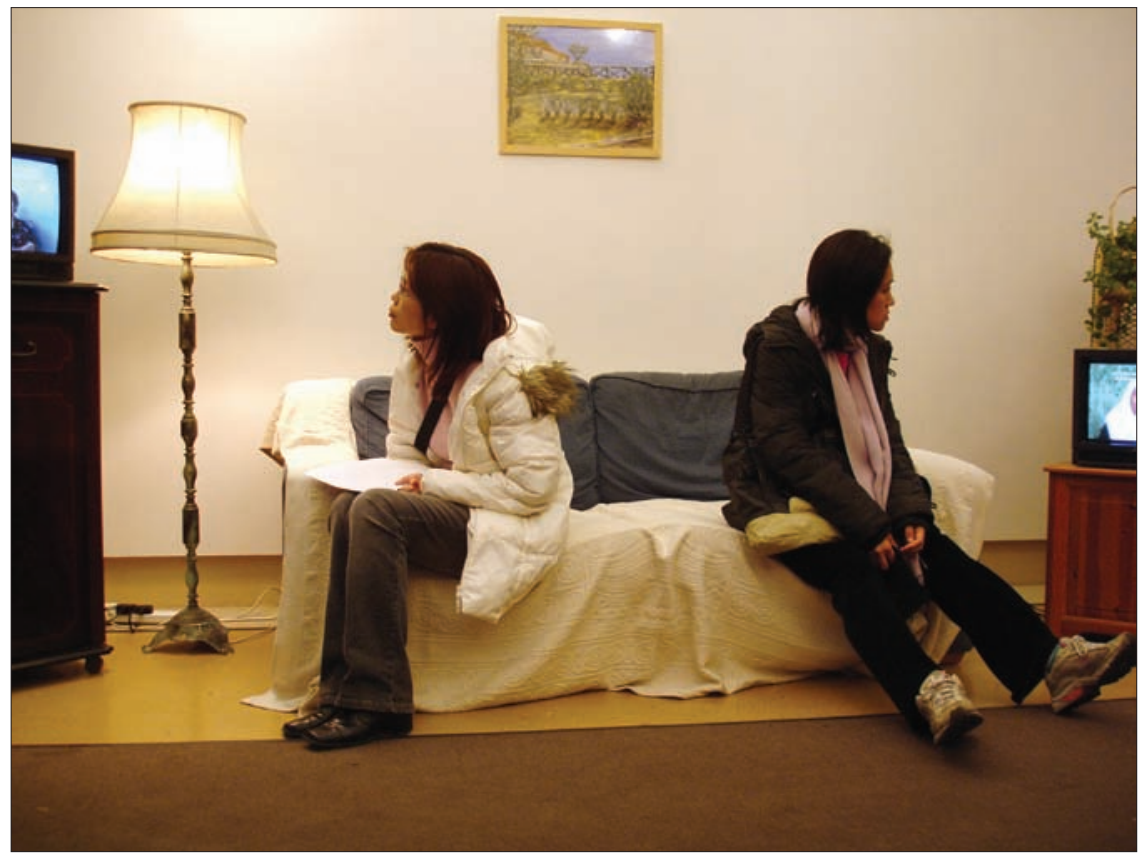

Fig. 4. Installation view of Nothing is Missing in the context of the exhibit Migratory Aesthetics, curated by Griselda Pollock, Leeds University, 2006. (C) Mieke Bal, 2006.

Visual communication between mother and child is effected face-to-face and, when those faces are smiling, everybody is happy, or appears to be. For most of us, the human face is not only the most important key to identification based on appearance, it is also the primary field of expressive action... ${ }^{8}$ (emphasis added)

The assumed link between these two sentences posits the equality of communication with identification and expression. This equation is grounded in the double sense of identification-as and with - that, I contend, underlies the problem of portraiture in Western art and to which my installation attempts to consider an alternative. I call that alternative "inter-facing."

\section{INTER-FACING}

The sociocultural version of this political ambiguity is most clearly noticeable in the dilemma of "speaking for" and the patronizing it implies, versus "speaking with" as face-to-face interaction. The self-sufficient rationalism of the cogito tradition is thus in collusion not only with a philosophical denial of second-

18. Richard Brilliant, Portraiture, p. 10. 
personhood but also with a subsequent denial of what faces, rather than expressing, can do. In order to move from an expressionism to a performativity of the face, the three uses of the preposition "inter-" I invoked a propos of Gatens and Lloyd's Spinoza need to be mobilized.

Intercultural relationality in its inscribed mobility of subjectivity posits the portrait, the face, as an interlocutor whose discourse is not predictably similar to that of the viewer. These women speak to "us" - but mind the gap! - as they speak to their own relatives, again, across a gap. The first gap is that of culture if we continue to view cultures as entities instead of processes. The second gap is that caused by "the cultural" conceived as moments and processes of tension, conflict, and negotiation. The people to whom the women tell their stories are close to them, yet distanced by the gap made by the migration of the loved one. The daughter-in-law, not chosen, of Massaouda, the son-in-law who took her daughter away, for Gordana, the daughter, granddaughter and great-grandson of Ümmühan: all are reaching out to the mothers across an unbridgeable gap produced by history.

These interlocutors are caught in the migratory aesthetics of a mobility "filled with" gaps - if I may be pardoned this oxymoron. The two simultaneous situations of speech-between the mothers and the viewer, and between the mothers and their relatives - doubly mark second-personhood. The theoretical and artistic alternative to artistic authority of a "willful abandon of mastery," 19 underlies the filming in my own absence.

Uhlmann points this out through Beckett, and he uses that same noun, gap: there is necessarily, not coincidentally, a gap between intention and artwork. Significantly and paradoxically, Uhlmann uses the discourse of mediumspecificity to make a point about the merging of domains, and the discourse of embodiment-sensations - to posit gaps. The gaps as entrance into sensations that are "borrowed" in a sense, grounded in someone else's body, open the door to the inter-face. Gaps, in other words, are the key to a migratory aesthetics that reject a romantic utopianism in favor of a difficult, hard-won but indispensable inter-facing. Gaps, not links, are also the key to intermediality. The two, my installation attempts to suggest, go hand in hand.

\section{INTER-TEMPORALITY}

This concept of the gap lays the ground, in turn, for the second partner in the exploration of inter-, namely inter-temporal thinking comes with the preposterous foregrounding of the present as starting point. These women carry the history

19. See Mieke Bal, Travelling Concepts in the Humanities. 


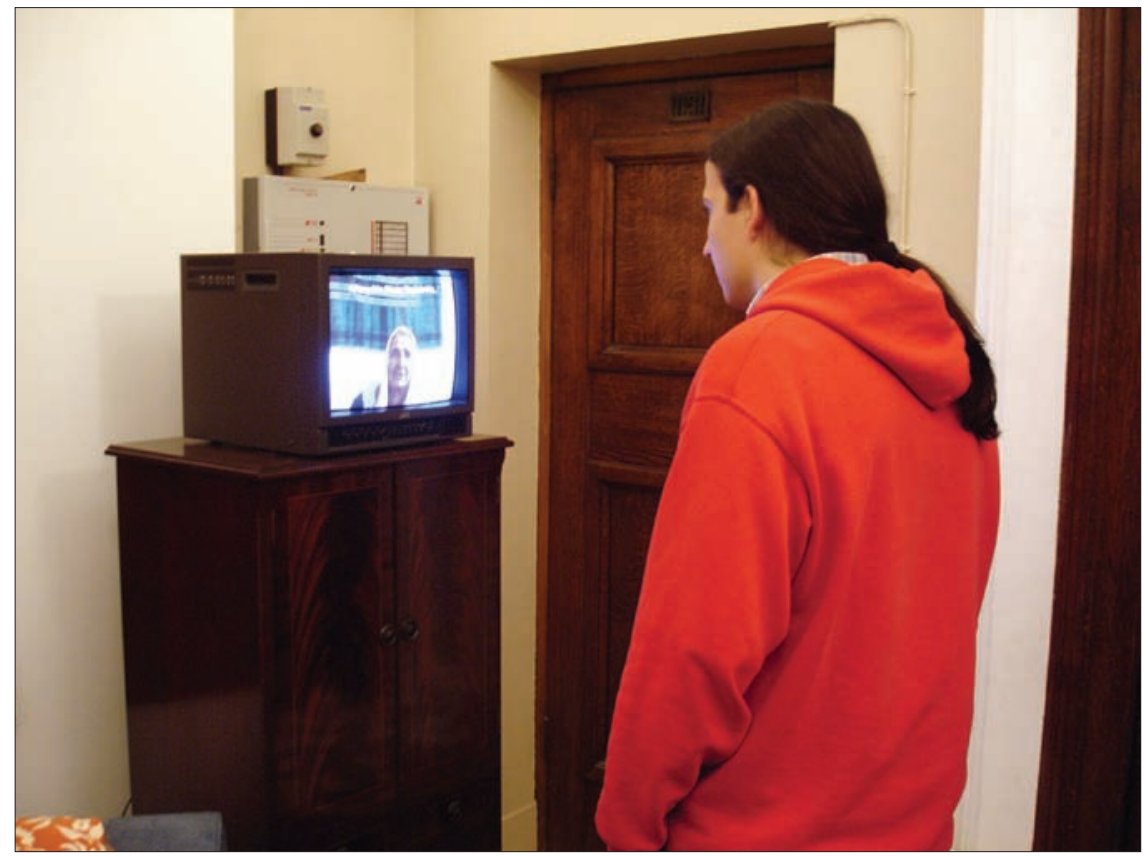

Fig. 5. Installation view of Nothing is Missing in the context of the exhibit Migratory Aesthetics, curated by Griselda Pollock, Leeds University, 2006. (C) Mieke Bal, 2006.

of the severance from their beloved child. They state their acceptance of that separation as a fact of the present. Moreover, the concept of video installation positions the copresence of the mothers with the viewer visiting the installation. Here lies one function of the acoustic gaps, the silences in the films. When she does not speak, it seems, the viewer's turn has come to speak back to her-to the mother who now just looks the viewer in the face.

The inter-temporality also plays out in the belatedness of the viewer's engagement. To understand the need for this engagement in its inevitable belatedness, two distinct steps need to be taken. The first makes the move from individual to social, the second from past to present. Invoking Spinoza's version of the imaginary as undeniably social in nature, Gatens and Lloyd write:

Intersubjectivity here rests on connections between minds which are grounded in the impinging of bodies which are both alike and different, giving rise to affects of joy and sadness, love and hate, and hope. (CI, p. 39)

If taken individualistically, that engagement cannot benefit any of the mothers, if only due to the temporal discrepancy between filming and viewing. Yet, in terms of inter-temporality, the promise of that engagement built into the making of the work did cause the women to voice satisfaction with the fact that, 
for the first time in their lives, they had been asked to speak to their loss and grief, joy and hope. At the same time, the social nature of intersubjectivity holds a performative promise of the improvement of the social fabric the imaginary enactment of identification will help build.

The images themselves fulfill a function in this inter-temporality. As Gatens and Lloyd recall:

$[\ldots]$ the complex interactions of imagination and affect which yield this common space of intersubjectivity, and the processes of imitation and identification between minds which make the fabric of social life. (CI, p. 40)

As a speech act, the promise is as binding as aesthetics. Therefore, aesthetic works may be eminently suitable to double-bind the women to a social world whose fabric allows their experience to be voiced, so that they can be relieved of carrying the burden too solitarily, instead of being caught in a double bind that forces them to silence. This is where the affection-image, that Deleuze theorized as emblematically situated in the close-up, comes in with its typical temporality. Close-ups subvert linear time. They perdure and thus inscribe the present into the image. Between narrative images and close-ups, then, a particular kind of intermediality emerges; one that stages a struggle between fast narrative and stillness. The inter-temporality at stake here takes its starting point from the present-the present of viewing. ${ }^{2 \circ}$

Marrati points to the crucial function of the affection-image as the closest to both the materiality of the image and that of subjectivity. She writes: "Between a perception that is in certain ways troubling, and an action still hesitant emerges affection." (GD, p. 48) It is this image, she continues, that transforms the movement of translation in movement of expression, "in pure quality." (GD, p. 49) This is why the affection-image remains closest to the present, while providing it with the temporal density needed to make the inter-face possible.

Gatens and Lloyd recall that Spinoza's conception of affect is explicit in its inter-temporality. They write:

The awareness of actual bodily modification - the awareness of things as present-is fundamental to the affects; and this is what makes the definition of affect overlap

20. Mark B.N. Hansen, "Affect as Medium, or the Digital-Facial-Image," Journal of Visual Culture, Vol. 2, No. 2, 2003, p. 205-228. For an excellent explication of affectionimages, see Patricia Pisters, The Matrix of Visual Culture: Working with Deleuze in Film Theory, Stanford, CA, Stanford University Press, 2002, p. 66-71, and Paola Marrati, Gilles Deleuze, Cinéma et philosophie, Paris, Presses universitaires de France, 2003, p. 48-54. Henceforth, references to this text will be indicated by the initials "GD," followed by the page numbers, and placed between parentheses in the body of the text. 
with that of imagination. All this gives special priority to the present. But there are two ways in which the present is involved in imagination and affect: first, the awareness of the immediate state of bodily modification, which applies, by definition, to all affects and to all imaginings; and, second, the special relation to the present which arises where not only the bodily modification but its causes are present-that is, where the affect relates to something here and now, rather than past or future. (CI, P. 52 )

The images that result from this are far from the documentary realism so dear to Western culture. Such images possess, as Marrati reminds us, a "temporal density" that is inhabited by the past and the future, while affect, hence, especially the affect produced by the close-up, remains an event in the present-an event of, to use a typical Spinozian-Deleuzian phrase, becoming. (GD, p. 88; CI, p. 52) Becoming concerns the presence of the past. If we take this presence to the realm of the social, we can no longer deny responsibility for the injustice of the past, even if we cannot be blamed for it. For, without that responsibility the use of the vexed pronoun "we" - "the full deceptiveness of the false cultural "we" - itself becomes disingenuous, even unethical. ${ }^{21}$

"Spinozistic responsibility" as Gatens and Lloyd call it, is derived from the philosopher's concept of self as social, and consists of projecting presently felt responsibilities "back into a past which itself becomes determinate only from the perspective of what lies in the future of that past-in our present." Taking seriously the "temporal dimensions of human consciousness" includes endorsing the "multiple forming and reforming of identities over time and within the deliverances of memory and imagination at any one time." (CI, p. 81). This "preposterous" responsibility based on memory and imagination makes selfhood not only stable but also instable. (CI, p. 82) This instability is a form of empowerment, of agency within a collectivity-based individual consciousness. In Deleuze's work, this becomes the key concept of becoming. (CI, p. 81-83; GD, p. 110)

\section{INTERFACE BETWEEN DISCIPLINES}

Becoming also defines our activities as scholars in the humanities, interacting with artists. Hence, finally, interdisciplinary thought is needed. This allows us to make the connection, in the present and across the cultural divide, between a number of discourses and activities routinely either treated separately or unwarrantedly merged. My own position in this dossier is, of course, an instance of interdisciplinarity/intermediality.

21. This characterization of the first person plural pronoun is from Marianna Torgovnick, "The Politics of 'We', in Marianna Torgovnick (ed.), Eloquent Obsessions: Writing Cultural Criticism, Durham, North Carolina, Duke University Press, 1994, p. 265. 
There are many issues here, of which I single out only a few. First, the most obvious case seems also the most problematic one: the place of psychoanalysis, the darling of some and a changeling for others. I do to dismiss the theory but give full weight to the mothers' enacted desire to refrain from self-expression.

First, the situation of filming, in the intimacy-with-gaps and in the absence of the filmmaker, could easily become a trap to solicit more self-expression than the women would want to endorse. But a degree of modesty becomes us here. For it is at moments of restraint, when they seem most reluctant to express themselves, (in the Western sense of that word) that the performativity of their selfpresentation is most acutely able to pierce through the conventional surface. A leap to the psyche might bypass these moments, while these moments are for me the keys to migratory aesthetics, to facing, and to intermediality. They are the moments of the performative inter-face.

Massaouda offers a striking instance of a culturally specific reluctance that cautions us against psychologizing or psychoanalyzing her. Not coincidentally, this is at the most strongly performative moment of the video. It is also a moment where performativity and performance in the theatrical sense of role-playing merge quite strikingly. This is the situation: as I have been able to see first-hand, Massaouda and her newly acquired daughter-in-law, Ilhem Ben-Ali Mehdi, get along famously. But in their relationship remains the stubborn gap immigration policy has dug. When Ilhem married Massaouda's youngest son, the mother was not allowed to attend the wedding: the authorities had denied her a visa. Hence, not only had Massaouda not been in a position to witness who Ilhem was, but even more obviously, she had not been able to fulfill her motherly role as her culture prescribes it, which is to help her son choose his bride. At some point, Ilhem ends up asking with some insistence what Massaouda had thought of her when she first saw her, after the fact, hence, in a kind of powerlessness. ${ }^{22}$

First, Massaouda doesn't answer, which makes Ilhem anxious enough to insist, and to ask: did you find me ugly, plain? The older woman looks away at this point. The young woman insists. We will never know what Massaouda "really" felt, but the power that the filming bestows on her, as if in compensation for her earlier disempowerment, is to either withhold or give her approval. She does the latter, but only after some teasing. When I saw the tape and understood

22. On the story of this marriage, see the art collective Cinema Suitcase's 2004 Mille et un jours, a 44-minute film distributed by VTape, Toronto, a commentary in Patricia Pisters, "Micropolitics of the Migrant Family in Accented Cinema. Love and Creativity in Empire," in Patricia Pisters, Wim Staat (ed.), Shooting the Family: Transnational Media and Intercultural Values, Amsterdam, Amsterdam University Press, 2005, p. 197-212, and photographs in Kathrin Becker, Masculinities, Berlin, Neue Berliner Kunstverein, 2005. 
the speech I was convinced Ilhem would never have been allowed to ask this question and thus vent her anxiety. As for the mother, she was given, and performed the power she had been denied, and she used it to first mark the gap, then to be kind, to help her somewhat insecure daughter-in-law.

This interaction is thoroughly social, performative, and bound to the medium of video-to the making of the film. As such, it is intermedial. But it does not allow psychoanalytic interpretation. Neither did I as maker have any influence on this occurrence-it was not my "intention." Nor can we construe it as a realistic, documentary moment where an "occasion" was recorded-it would never have happened outside of the situation of video-making. There would never have been an external reality the film could have documented. It is a moment, in other words, that was staged, yet real, thus challenging that distinction. Nor can we pinpoint a psyche offering symptoms for interpretation. For this to happen there was, instead, a need for a culturally-specific relationship between two women related by marriage and separated by the gaps of migration; and for a relationship to the medium that allowed the women to overstep cultural boundaries. Thus, the suspension of the categories of the individual psyche, and in its wake, of intention, demonstrates a level of interdisciplinarity I am particularly keen to point out. What happens, here, is an instance of what Maaike Bleeker calls the mission of theatre, as a "critical vision machine."23

Thus, my willful abandonment of mastery extends from the filming to the critical discourse I am offering, the reflection on what I have learned from this experimental filmmaking. The filmmaking, performed by the women in their inter-face with their relatives first of all, indicates it is appropriate to take to the resulting installation. An installation of voices, intermingling and alone, and of faces, facing women none of them has ever seen. The art-making, in other words, is not an instance, an example to illustrate an academic point, nor an elevated form of cultural expression to which no criticism can do justice. Instead of these two things, equally problematic for a productive interaction between art and theory, the performance, including the moment of slight tension between Massaouda and Ilhem is a genuine form of research, the results of which impinge on what we grope towards articulating as an academically fruitful concept. Through this tension, the full potential of facing has become clear to me in ways it had not been before.

23. This phrase is Bleeker's short definition of the theatre's specific capacity to produce visions that do not fit cultural standards, and thus make it a suitable tool for migratory aesthetics. See Maaike Bleeker, Multicultureel drama?, Amsterdam, Amsterdam University Press, 2006. 
The performative moment is the product of an act of filmmaking that required the absence of the filmmaker. But more than that; it also required the surrender of the two women to the apparatus standing in between them. This surrender entailed a cultural transgression-to ask, and insist on, a question that in the culture of origin would be unspeakable. This, more than her linguistic pronunciation of Arabic as a second language, is Ilhem's "accent," in the sense in which Hamid Nafici famously uses that term. ${ }^{24}$ This "accent" emblematizes the productive, innovative and enriching potential of intercultural life. In this case, it could occur thanks to the absence of the filmmaker-but also of the two husbands - and the situation of displacement for both. And I learned about and from this event after the fact, during the translation process, with Ilhem's husband who was as astonished as I was. This interdisciplinarity-between the people performing and the critic reflecting on how to understand what they did-would be stifled if a too well-known psychoanalytic apparatus were let loose on this event. ${ }^{25}$

A second issue of interdisciplinarity is especially significant for this journal. I am alluding to an aspect that is essentially, not coincidentally involved in migratory aesthetics: the linguistic situation as intermedial. The spoken word is central to the installation in many ways and on many different levels, all of which converge in the attempt to turn a condescending act of "giving voice" into an affirmation of our need to be given that voice in order to exist. This is why I announced earlier that the medium of video is especially appropriate for migratory aesthetics, and facing the emblematic instance of such an aesthetic. Video, like film but more directly, binds the image we see to the sound we hear. That sound is, in this case, primarily and almost exclusively the human voice and the spoken words it utters.

First, the centrality of the spoken word impinges on the visual form, the close-up. For, it is also in order to foreground the privileging of the voice of the mothers that the films consist of single shots of their face as they speak and listen, and remain unedited. The personal situation presupposes sincerity. At the same time, they are keenly aware of the public nature of the speech they are producing in front of a camera. The nature of this performance is closer to theatricality, in the critical sense, than to traditional filmmaking. As theatre, the situation is

24. Hamid Naficy, An Accented Cinema: Exilic and Diasporic Filmmaking, Princeton, Princeton University Press, 2001.

25. It may sound paradoxical, but psychoanalysis as a theory would be in agreement with this reluctance to apply it, if we are to believe Shoshana Felman's point about the need to not know as psychoanalysis's primary contribution to pedagogy. Shoshana Felman, "Psychoanalysis and Education: Teaching Terminable and Interminable," Yale French Studies, No. 63, 1982, p. 21-44. 
closer to minimally rehearsed, improvised, and inquiring forms of theatre than to perfectly mastered public forms. ${ }^{26}$

Second, the intermediality has been foregrounded graphically. The translations presented as surtitles also embody the close bond between linguistic and visual aspects of the images - the bond between face and speech. As I mentioned, the viewer is confronted with four different languages, foreign to most, audible in their foreignness and visible in an emphatically visualized translation. Placed, visually, above their faces, the language is both made important and presented as somewhat of a burden. English as the sole entrance port is denaturalized, both by this visual foregrounding and by the translations themselves.

Third, translations are as literal as possible, bringing out the poetry in the original languages without sacrificing to clarity. None of the translators are native speakers of English. Their assignment was to help me stay as close as possible to the phrasings the women used. This method results in an "accented" English, that maintains the bicultural status of the communication.

Finally, the most acute intermediality occurs in the faces, which visibly produce the sound of the voices, the language we do not understand, and the need to translate, all in one. It is really difficult to separate sound from vision, as the mouths articulate with the rhythm of the sounds. Video, that easy-to-transport engine to make home images and home speech is the medium of this intermediality. This is not simply a case of the "moving image" of cinema. Instead, the moving quality becomes a poetic, a self-reflective statement about the medium that reintegrates what the predominance of English, the home-boundness resulting from a lack of education, in turn aggravated by misogyny and colonialism, have severed. The face and its acts, thus, becomes the emblematic instance of video's power to transgress boundaries of a variety of kinds.

\section{MIGRATORY AESTHETICS: WHAT THE FACE CAN DO}

Migratory aesthetics, then, addresses specific issues of "binding through the senses" the gaps or remainders of the mobility that has always been part of Western culture, although we didn't realize it. In Nothing is Missing, I do address actual

26. I am thinking of the theatrical performance in Zaire, described by Johannes Fabian, which was set up to examine the meaning of a proverb. Johannes Fabian, Power and Performance: Ethnographic Explorations through Proverbial Wisdom and Theater in Shaba, Zaire, Madison, University of Wisconsin Press, 1990. See also Maaike Bleeker, Multicultureel drama?. 
migration, but not as the thematic heart of the work. That heart, rather, is the encounter with the faces. ${ }^{27}$

The focus on the face embodies the act of facing in its three meanings, all three staged here as acts of mutuality. First, the emphasis on activity reflects back on the face itself. No longer the site of representation and expression, the face has become an agent of action: what can faces do, rather than how to do things with faces. ${ }^{28}$

The face faces, looking us in the face, making the viewer the interlocutor. It faces something that is hard to live down, here, the severance of the primary bond that humanism construes as defining of humanity: that between mother and child. In these videos of acting faces, that event is qualified as larger than the individual. All four women speak in understated tones of the causes of the child's departure in terms for which Western cultures can assume some measure of historical responsibility, if only "we" reason with Spinoza. Gordana speaks of war, Massaouda of hunger, and Ümmühan of culturally sanctioned domestic violence.

The severances, different as they are, and differently related to the past, are lived as what for me is the ultimate tragedy: that the mothers, all of them, say that they are happy about the sore fact that their child left. These backgrounds are understated because they can neither be eliminated from the present, nor be allowed to overrule the existence of the mothers in an everyday that is also rich and sometimes happy. Hence, the discourse intimated in the installation's title-he one on which Massaouda ends her finally and hard-won openness about what matters most to her as a mother: that her son finds bread to eat. Facing these present pasts, and the kind of motherhood that results nevertheless fulfills the becoming of who we are in the present: according to the binding implied in migratory aesthetics, facing these pasts together so that "we" can "be" is part of our own potential of becoming.

But how can we do that? Making contact, the third act implied in facing, facilitates that becoming-becoming world citizens, building our existence on mobility without having to move. This making of contact is suggested as an

27. For a recent theoretical discussion of the concept of everyday life, see Claire Colebrook, "The Politics and Potential of Everyday Life: On the Very Concept of Everyday Life," New Literary History, Vol. 33, No. 4, autumn 2002, p. 687-706. For another instance of video as a tool for a discussion of the everyday in migratory aesthetics, see my article, "Food, Form, and Visibility: GLUB and the Aesthetics of Everyday Life," Postcolonial Studies, Vol. 8, No. 1, 2005, p. 51-73.

28. See Richard Rushton, "What can a Face Do? On Deleuze and Faces," Cultural Critique, No. 51, spring 2002, p. 219-237. 
effect of the insistent facing in Nothing is Missing. What faces can do, as Richard Rushton puts it, is staging encounters:

[...] when I come before another person [...] I enter into a realm of possibility, of possible connections, of possible confrontations, expectations, creations; in short, I enter into possibility itself. An endless possibility is, however, channeled by the specific possibilities I come across when I come before another. This experience of circumscribing and of curtailing possibility is the experience of the face. ${ }^{29}$

This is the point of the faces of the mothers in Nothing is Missing-their empowerment. In the installation, the face is constantly present, in close-up but not as close as possible. As a visual form, the close-up, Deleuze wrote, is itself the face:

Il n'y a pas de gros plan du visage. Le visage, c'est le gros plan, mais un visage précisément qui a détruit sa triple fonctionnalité [individuation, socialization, communication] [...] Le gros plan fait du visage un fantôme, et le livre aux fantômes [...] Le visage est le vampire. $3^{\circ}$

If the close-up is the face, the face is also the close-up. Hence, the slight distance nevertheless built into the image, to avoid locking the viewer up and denying the women any space at all. To avoid facile conflation, and appeal to sentimentality. To give the face a frame within which it can exercise its mobility and agency, as it can within the veil that signifies Muslim identity. To make the images look like the busts of Roman emperors and other dignitaries. That slight distance, then, provides the space for a freedom à la Spinoza. Such a freedom is "critical," in philosopher James Tully's words. Critical freedom is the practice of seeing the specificity of one's own world as one among others, and inter-temporally, this freedom sees the present as fully engaged with the past that, insofar as it is part of the present, we can a little more freely rewrite. The act of inter-facing can do that. This capability lies at the heart of migratory aesthetics, defined as a binding mobility. ${ }^{31}$

29. Richard Rushton, "What can a Face Do?," p. 228.

30. Gilles Deleuze, Cinéma 1. L'image-mouvement, Paris, Éditions de Minuit, coll. "Critique," 1983 , p. 125.

31. Gatens and Lloyd's final words (CI, p. 149) alerted me to Tully's concept of critical freedom, and his book which I read belatedly as a result. See James Tully, Strange Multiplicity: Constitutionalism in an Age of Diversity, Cambridge, Cambridge University Press, 1995. 